\title{
Behaviors of EFL Students on Cyber Classes: Passive presence in Google Classroom; survey of causes and attitudes
}

\author{
Mustafa Salem Braiek \\ English Department, Faculty of Arts, Misurata University \\ mustafabreik@art.misuratau.edu.ly
}

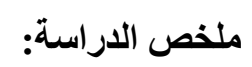

توفر الفصول التي تستخدم التكنولوجيا والانترنت في التدريس مساحة للمعلمين والطلاب

لتوسيع وتعزيز التفاعل داخل الفصل، والانخراط في مناقشات هادفة وتبادل الأفكار والمعلومات والمصادر ذات الصلة. وتتجلى مزايا هذه الفصول التي تدمج التكنولوجيا في التدريس في كوها توفر الوقت والجهاد الذي يستثمره المعلمون والطلاب في العملية التعليمية. وتمدف الدراسة إلى دئل

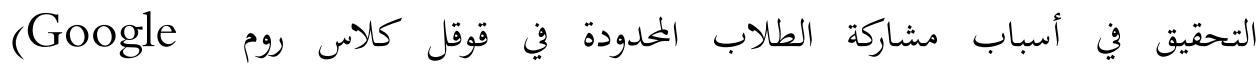

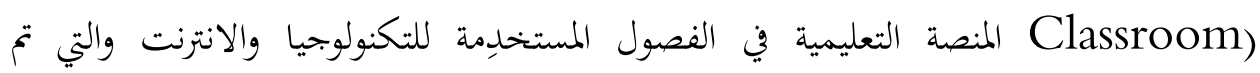

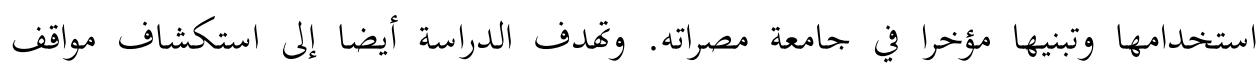
الطلاب بحاه استخدام طريقة (Google Classroom). المشاركون في هذه الدراسة بلغ (58) طالبا وطالبة بقسم اللغة الإبحليزية، كلية الآداب، جامعة مصراتة. استخدمت الدراسة

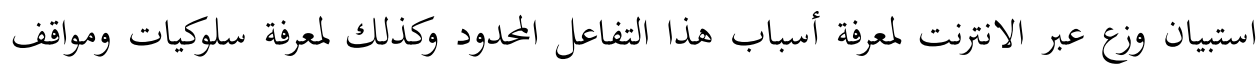
الطلاب بحاه هذه الطريقة التي تستفيد من التكنولوجيا ودروس الإنترنت. أظهرت نتائج الدراسة

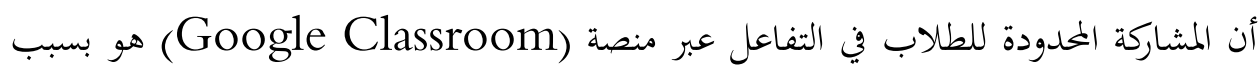

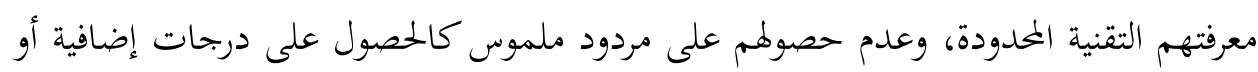

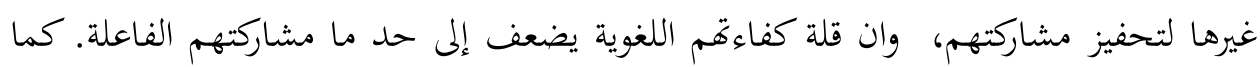
أظهرت النتائج أيضا، أن مواقف معظم الطلاب المشاركين في هذه الدراسة كانت إيجابية بحاه استخدام (Google Classroom). 


\begin{abstract}
Cyber classes provide space for teachers and students to extend and consolidate classroom interactions, engage in meaningful discussions and share ideas, information, and relevant materials. The potential merits of cyber classes are obviously bound to the amount of time and effort invested therein by the involved parties, i.e. teachers and students. The current study aims at investigating the causes of limited participation of EFL students in Google Classroom as the recently adapted cyber class platform at Misurata University, as well as exploring the EFL students' attitudes toward Google Classroom. 58 EFL students at the department of English in Misurata University responded to a questionnaire probing their displayed behaviors on cyber classes. Even though the results showed that most EFL students had positive attitudes toward using Google Classroom, they tend to be passive users of cyber classes due to technological concerns, language proficiency to some extent, and failure to perceive tangible outcomes.
\end{abstract}

Key words: Cyber classes, Google Classroom, ELT students, e-learning, $G$-class, passive presence.

\title{
1. Introduction
}

The twenty-first century has witnessed a huge progress and development of different types of technology in different fields language education. Flakes (2011) stated that technology provides a platform for teachers to effectively reach learners of different learning styles. Students today are comfortable with electronic devices and keen on social contexts and collaborative activities. Therefore, integrating technology in the educational process has become a necessity in our time to guarantee environments that encourage participation, a variety of activities, group working, and critical thinking instead of memorization 
and passivity that in turn makes them not capable of growth and development (Alsowat, 2016).

In order to keep up the pace with the technological developments and follow the new styles of teaching and learning which benefit from the current modern technologies and the Internet, some teachers of English in Misurata University adopted Google Classroom as a cyber class platform in teaching English to consolidate classroom interactions. However, the students showed limited participation with the teachers in Google Classroom. The current study aims to investigate the causes of passive presence of students in EFL cyber classes at the department of English in Misurata University, as well as their attitudes toward Google Classroom.

\subsection{Statement of the Problem}

Using Google Classroom as a platform in teaching English is a new trend adapted by most of the staff members at the previously mentioned department. The staff members attempted to benefit from the current advancing technology via integrating it into teaching in order to facilitate the educational process. However, it has been noticed that students have had limited participation in Google Classroom. Therefore, the current study investigates the causes behind such passivity in using what is thought to be motivating factor.

\subsection{Hypothesis}

The study hypothesized that passive students' participation in Google Classroom may be due to the following themes: technical literacy, language proficiency, and missing tangible outcomes that motivate students to participate effectively. 


\subsection{Research Questions}

The current study tries to find answers to the following questions:

What are the causes of students' passive presence on G-Class?

What are the EFL students' attitudes toward Google Classroom?

\subsection{Significance of the Study}

Being the strategy of using Google Classroom as a platform in teaching is a relatively new trend in the Libyan context, there seems a lack of research conducted about using cyber classes in teaching English. Thus, the findings of the current study may contribute positively to the literature on the nature of the field of ELT in Libya. Furthermore, the study might draw the attention of teachers to the students' behaviors and the effectiveness of using Google Classroom as a platform in teaching English, as well as the real causes that make students do not participate actively so that they can be taken into consideration a head of time.

\section{Literature Review}

\subsection{Importance of Using Technology in Language Classrooms}

Graddol (1997) stated, "technology lies at the heart of the globalization process; affecting education, work, and culture. The use of English language has increased rapidly after 1960" (p.16). Therefore, in order for foreign language teachers to teach language, they may use technology in their classrooms to reach many of their goals in a more efficient and practical way. Thus, implementing technology in language classrooms can serve such goals in different ways, for instance, bringing the target culture inside classroom to make the learning process more visible. In addition, 
technological tools can give teachers additional resources to reach different types of learners as well as enhancing the amount of interaction inside and outside the regular classroom. In short, technology is one of the most significant drivers of both social and linguistic change. Patel (2013) found that "technology provides so many options as making teaching interesting and also more productive in terms of improvements" (p. 116).

\subsection{Context of the Study}

Being the learner basically the focus in the learning process, the present era then assigns new challenges and duties on the modern teacher. The tradition of English teaching has been changed with the remarkable entry of technology in most of the countries. Language teachers in turn must utilize technology in a way that is intentional and purposeful. Abukhattala (2016) stated that "teachers need to adopt a different role; they need to be facilitators, rather than the traditional bench-bound instructors, and they need to support and guide students' learning” (p. 263).

Since there are more and more English language learners all over the world, and in Libya, here as a case in point, different teaching strategies have been implemented to test the effectiveness of the teaching process. Libyan universities in general and Misurata University in particular have started considering moving toward utilizing more technology for achieving the best possible educational outcomes. One step was offering 
the chance for teachers and students to use cyber classes, namely Google Classroom, where teachers can create online platforms for enhancing the efficiency of the taught courses. Flake (2011) justified that "Having class only once a week is a limited learning schedule that is potentially ineffective for advancing ESL learners - the Cyber Classroom enables the student to effectively use time between classroom meetings" (p. 34). Teachers and students can interact in a much easier way and at any time by sharing related materials such as videos, having online discussions, or simply following up with the lectures.

\subsection{Related Studies}

A study conducted by Canning-Wilson (2000) argues that as educational technology moves closer and closer towards eliminating the practices of traditional classroom teaching, on-line teaching and learning will become a more practical and viable solution to meet the demand for learners' educational needs. It concluded that EFL teachers must consider e-course objectives, the e-content, the e-policies and e-procedures, the e-evaluation of the course and instructor, the e-office hours and of course how to deal with e-problems, which will arise during the online courses. Beyond the basics listed above, the online teacher when designing a course must also consider how he/she will deal with the emotional, psychological, and learning style of the perspective online student.

Arifah (2014) conducted a study on the Use of Technology in ELT Classroom aimed to investigate the teachers' views about the use of multimedia and internet in classrooms. The study also tried to find out about teacher's training about technologically advanced classroom. The 
study adopted a survey as a research method (quantitative and qualitative). The participants were teachers selected from the colleges in Dhaka, Bangladesh. A questionnaire, an observation, and a focus group interview, were the tools of data collection. The findings of the study revealed that students were very enthusiastic to learn language through technology, and if the use of technology and internet were introduced for teaching and learning, learners would be motivated to learn the language accurately and learn how to use it in real life.

DiCicco Kathleen M. (2016) carried out a study about the Effects of Google Classroom on Teaching Social Studies. The study aimed to examine the effects of Google Classroom on teaching social studies for students with learning disabilities. The participants were six $7^{\text {th }}$ graders, attending a resource classroom. To evaluate the participants learning outcomes of content and vocabulary, a single subject design was used. A traditional way of teaching was used to teach the students during the baseline. During the intervention, the students were asked to complete different assignments using Google Classroom daily for 9 weeks. The students were assessed by tests and quizzes using Google Classroom. To evaluate the students' perspectives about the integration of Google Classroom into social studies instruction, the researcher gave a survey to teachers and students. The results of the study showed that integrating Google Classroom into social studies instruction demonstrated students' positive learning outcomes in vocabulary test but limited in content knowledge.

Another study carried out by Rovai and Barnum (2003) under the title "On-Line Course Effectiveness: An Analysis of Student Interactions and 
Perceptions of Learning". The aim of the study was to determine how perceived learning varies by course and its relationship to students' active and passive participation in online discussions. The study analyzed nineteen online graduate courses. The results of the study provided evidence of significant differences existed by course, suggesting that quality assurance is an issue in Internet-based instruction. Furthermore, only active interaction, operationalized by the number of messages posted by students per week, was a significant predictor of perceived learning. Passive interaction, analogous to listening to but not participating in discussions and operationalized by the number of accesses to the discussion boards of the e-learning system each week, was not significant.

\section{Methodology}

The purpose of this study is to find the reasons why the students are unable to reach to the desired goal in using the Google Classroom platform as it should be. For this, this paper seeks to investigate the students' behaviors and attitudes toward such technological implementation by analyzing the responses made by EFL students. Our subject was the university level students. Their field of study was English language. An online survey method was implied for the study.

\subsection{Participants}

The participants of the present study were 58 (6 males and 52 females) EFL university students whose major is English. Their levels ranged from the $2^{\text {nd }}$ to the $7^{\text {th }}$ semester at department of English, Faculty of Arts, Misurata University. Regarding the levels of the participants, the majority 
(46.6\%) were juniors, while the minority $(12.1 \%)$ were sophomores, the seniors were $(13.7 \%)$, and (27.6\%) students were freshmen.

\subsection{Instruments}

A survey questionnaire was used as a tool of data collection. The questionnaire consisted of twelve close-ended questions containing 32 items. It was administered online to students to elicit their perceptions toward using Google Classroom, its effects, and the causes of the passive participation. (See appendix A).

\subsection{Procedure}

The questionnaire was delivered randomly online to 60 students from the $2^{\text {nd }}-7^{\text {th }}$ semesters at the department of English, Faculty of Arts, Misurata University, during the academic semester of Fall 2017. However, two responses were discarded as they were turned in blank, and ending up with receiving 58 responses; specifically, they were 6 males and 52 females.

\section{Data Analysis}

After gathering the data through questionnaire, the researchers analyzed them in a systematic manner. The researchers used closed-ended questions in the questionnaire. There were total 12questions in the questionnaire. After collecting responses of close-ended questions، the researchers analyzed the data on a scale of 58 and demonstrated them in percentage by using Google Forms. The overall results were shown in (Figure10).

\subsection{Findings and Discussion}


This section contains findings, analyses, and discussions of the data collected through the questionnaire. It was important first to know whether the students agree or disagree about the following statements:

1- I prefer to ask questions for the teacher face-to-face rather than post them on Google Classroom.

2- I can understand lessons well even if teachers use only English to give instructions and explanations.

3- I learn better, when teachers use Google Classroom than when they do not.

4- Attending some technology training courses will increase my participation on Google Classroom.

5- If I have an idea that I cannot express in English, I would rather speak in Arabic than be quiet.

6- I like the idea of rewarding participation on Google Classroom with marks.

The results of the first statement showed that (22) out of (58) students agreed preferring asking questions face-to-face rather than posting them on Google Classroom, (9) students were strongly agreed, whereas (19) students disagreed and (8) students were strongly disagreed. It is clear from the result that the majority of students avoid posting questions on Google Classroom; such a result confirms that there is a limited presence on Google Classroom.

In the second statement, (27) students agreed and (16) students strongly agreed that they can understand lessons well even if teachers use only English to give instructions and explanations, while (11) students disagreed, and only (4) students strongly disagreed with it. This result 
indicates that the language proficiency might not be the reason behind the low participation on Google Classroom, since the majority of students can understand well when using only English.

Results of the third statement showed a positive attitude regarding the use of Google Classroom. However, a negative view was also reported. Specifically, (24) students agreed that they learn better, when teachers use Google Classroom than when they do not, and (3) students strongly agreed. Whereas, (24) students disagreed, and (7) students strongly disagreed.

In the fourth statement, the results showed that (31) students agreed, (17) students strongly agreed that attending some technology training courses will increase their participation on Google Classroom, while (6) students disagreed and (4) students strongly disagreed. It is clear from the result that the students have some technical problems in using Google Classroom and this confirms the hypothesis that suggests that the passive presence on Google Classroom is because of technical literacy.

The results of the fifth statement showed that the language proficiency was not a matter in the participation since students would rather speak in Arabic than be quiet when they have an idea that they cannot express in English. Specifically, (29) students agreed, (12) students strongly agreed, whereas, (13) students disagreed and only (4) students strongly disagreed. In the sixth statement (I like the idea of rewarding participation on Google Classroom with marks), the results showed that (22) students agreed, (16) students strongly agreed, while (16) students disagreed and (4) students strongly disagreed. As we can see, the majority of participants welcome 
the idea of rewarding participation with marks. Such a result confirms that tangible outcomes might motivate participation effectively. (See Figure 1)

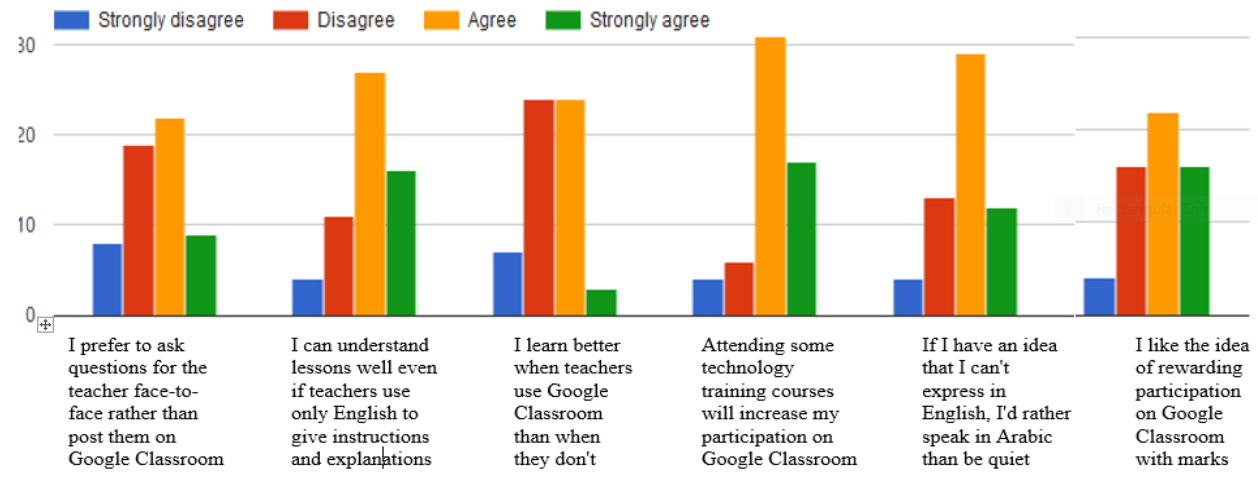

Figure (1). Students' behavior toward using Google Classroom

The next question of the questionnaire contained a number of statements aimed to know whether students agree or disagree about:

1-Google Classroom is easy to use (e.g. view class materials, ask questions, submit assignments).

2- I prefer if teachers and students could use both English and Arabic on Google Classroom.

3- I would like to use Google Classroom with other courses in the future.

4-Some teachers make Google Classroom less helpful by insisting on using English.

5- I will be more active on Google Classroom if my English gets better.

Results of the first statement showed that the majority of students (29) agreed that Google Classroom is easy to use, (23) students were strongly agreed, while (5) students were disagreed, and only one participant was strongly disagreed. This result refers that students' passive participation 
might not due to the ease or the difficulty of using Google Classroom. In addition, it refers that the students have a positive attitude toward using G-class. In the second statement, the results showed that the majority of students disagree if teachers and students could use both English and Arabic on Google Classroom. Specifically, (26) participants were disagreed and (6) students were strongly disagreed whereas (18) students were agreed and (8) were strongly agreed. This result indicates that the level of students' language proficiency might be good enough to help in participation without any need in using Arabic. Therefore, we can say that language proficiency might not hinder the participation on Google Classroom.

Moving to the third statement (I would like to use Google Classroom with other courses in the future), results showed that the majority of students (25) and (23) were agreed, and strongly agreed, while (2) participants were strongly disagreed, and (8) were disagreed about using Google Classroom with other courses in the future. This finding indicates that using Google Classroom has facilitated learning for students and has had a positive impact on them.

The results of the fourth statement (Some teachers make Google Classroom less helpful by insisting on using English) showed that (40) students were disagreed, and (6) were strongly disagreed, however, (11) students were agreed and only one student was strongly agreed. Such a result indicates that students were able to communicate and participate in English, thus, this might confirm that the language proficiency is not the case of passive participation.

At last, results of the fifth statement showed that (25) students agreed that they will be more active on Google Classroom if their English gets better, 
and (19) students strongly agreed, While (11) students disagreed and only (3) students strongly disagreed. This could be justified to the lack of confidence in using language in a professional manner since students tend to be more quocious when participating and writing to their professors. (See Figure 2)

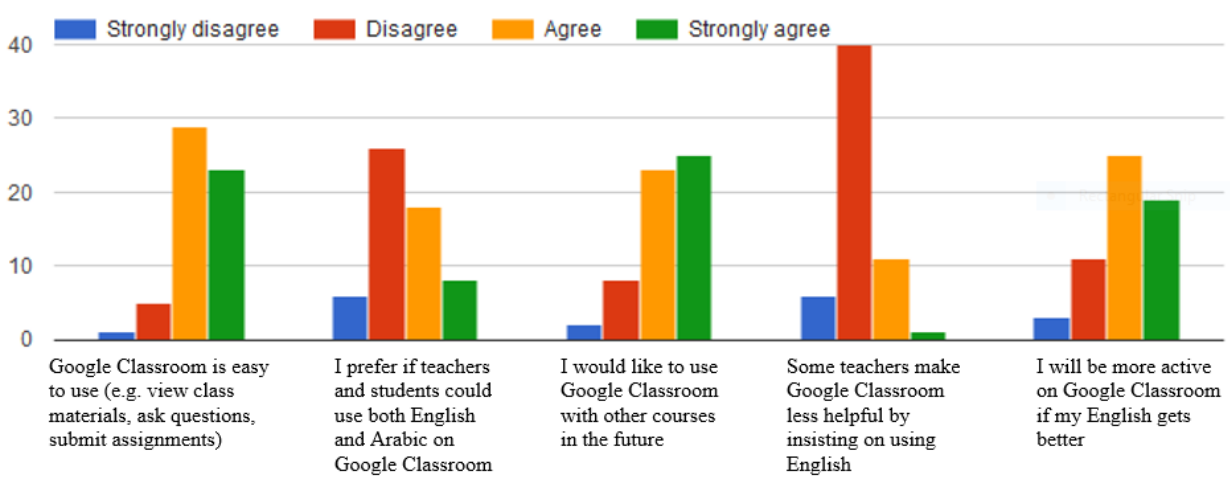

Figure (2). Students' opinions about Google Classroom and its uses

To know about the value of the content of Google Classroom, students were asked to rate (from 1 to 5) the following: [Lecture notes/slides, Group discussion/interaction, Assignments/quizzes, Extra materials (explanatory videos, further reading...etc.), Teacher feedback and assessment].

Results showed that (Teacher feedback and assessment) content had the highest rate $(23 \%)$ followed by (Lecture notes/slides) content $(20 \%)$, then (Extra materials) content (19\%), however, (Group discussion/interaction) content got the least rate $(11 \%)$. This means that the students considered the group discussion and interaction were not valuable, which might be an issue in terms of participation presence on Google Classroom. (See Figure 3) 


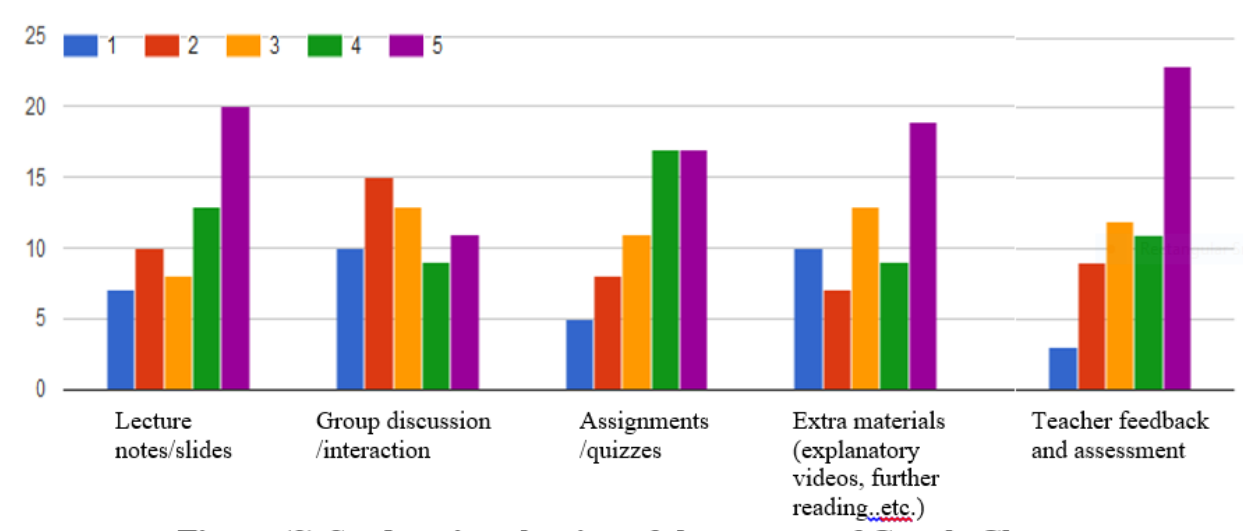

Figure (3) Students' evaluation of the content of Google Classroom

The next question of the questionnaire was asked to know how often the internet accesss was available to the survayed students. The results showed that all the students have had internet access. Specifically, an equal number of responses (46.6\%) chose (frequently - always), whereas only $(6.8 \%)$ answered (rarely). Such a result, therefore, weakens the justification that the passive presence on Google Classroom might be due to the lack of internet access at the students' homes.

The students' proficiency at using online services, then, was considered. To come to a better understanding of the students' profeciency levels, they were asked about their knowledge regarding the use of four online services: Social media (Facebook, twitter...etc.), Emailing (Gmail, Hotmail...etc.), Search engines (Google, Yahoo...etc.), Video sharing sites (Youtube, Dailymotion...etc.). Their responses also icluded where they see themselves in the four proficiency levels: non-users, basic users, independent users, and proficient users. (See Figure 4).

Starting with the first area of online services which is using social media (Facebook, twitter...etc.) 
The non-users were only (3), the basic users were (15), the independent users were (24) which is the highest, and finally the proficient users who were (16). It is clear here that the majority of the students whether basic, independent, or profecient users, who represent about 95\%, were aware of how to use social media.

Moving to the next online service, i.e. emailing (Gmail, Hotmail...etc.), the reserchers received the following division: (9) non-users, (25) basic users, (18) independent users, and only (6) described themselves as proficient users in using emails. This result reveled that about $16 \%$ do not use this very important on-line service. This could be justified to the lack of confidence in using language in a professional manner since students tend to be more quocious when writing emails to their professors. Nevertheless, the other students (about 84\%) indicated that they use emailing with no major issues.

After that, the use of searching engines (Google, Yahoo...etc.) came to be asked about. The students reported the following: (5) non-users, (22) basic users, (16) independent users, and finally (15) proficient users. Again, here if the non-users were excluded and only the latter three types of users were considerd, it could be stated that the majority (about 92\%) were aware of how to use searching engines with the majority (about 38\%) being basic users.

At last, the use of video sharing sites (Youtube, Dailymotion...etc.), the participants were devided as the following: (13) non-users, (21) basic users, (18) independent users, and only (6) proficient users. Having 13 participants (out of 58) who reported their being nonusers of video sharing sites might be considerd an issue since this means that those students are 
not making use of the available data such as lectures, documentaries. Yet, this is still considered a minor issue in regard to using Google Classroom. (See Figure 4)

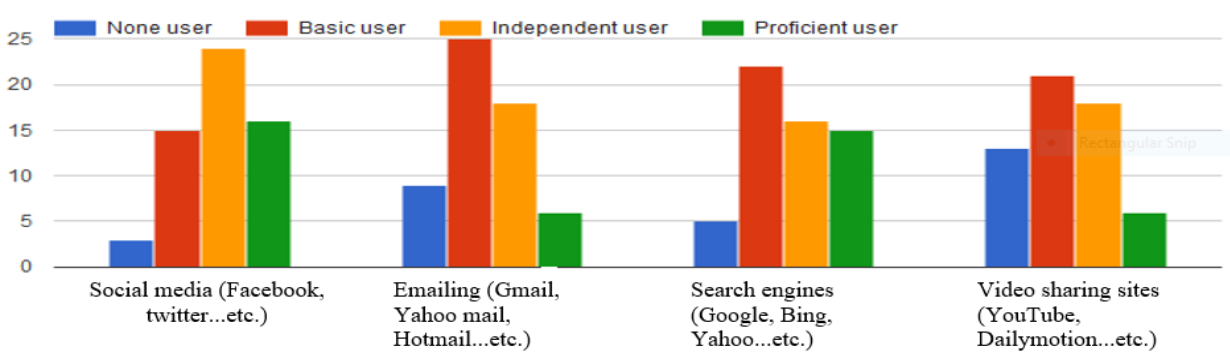

Figure (4). Students' proficiency at using online services

The next question of the questionnaire was about the number of courses students have attended in which they had some online communication with the teacher and/or students, to know whether the experience of using G-classes affect the participation or not. Results showed that the majority (32) of students attended 1-3 courses, and (15) students attended 4-9 courses while (4) students attended 10 or more. However, (7) students did not attend any online communication courses. (See Figure 5). As we can see, the majority of students experienced using Google Classroom and this indicates that this experience may not help some students to participate effectively.
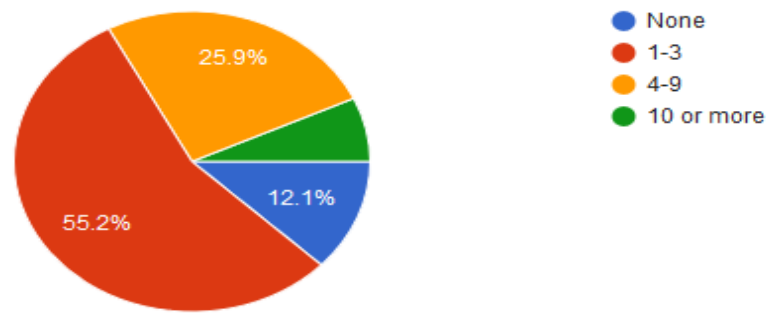

Figure (5) Number of online communication courses attended 
Concerning the following up of Google Classroom updates, participants were asked about the frequency of checking Google Classroom for updates. The results showed that the majority (39) students with a percentage of $(67.2 \%)$ checked Google Classroom for updates once or multiple times a day. (See Figure 6). The result confirms that all the students had internet access, as well as it indicates that the passive participation on Google Classroom might not be due to the lack of internet access or the frequent use of checking updates of Google Classroom.
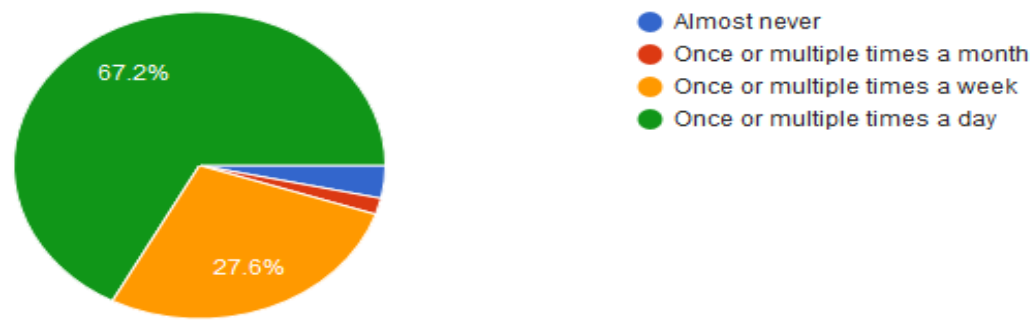

Figure (6) Frequency of checking of Google Classroom for updates

The next question of the questionnaire was placed to know how often the students find themselves making the following actions when visiting Google Classroom:

1- View or download class materials.

2- Respond to posts by the teacher or other students.

3 -post questions for the teacher or other students.

4- Submit assignments or quizzes.

The results showed that the majority of students always/frequently viewed or downloaded class materials and submitted assignments or quizzes, whereas, they rarely posted questions or responded to posts. Specifically, (26) participants did it frequently, (20) students did it always, while (8) 
participants did it rarely, and (4) of them never did it. Concerning the responding to the teacher or students' posts, the results showed that (28) of participants frequently responded, (23) of them rarely did it, while (7) students always responded, However, none of them never did it. As for the action (post questions for the teacher or other students) it was rarely done by (31) participants, and never done by (17) students, However, it was frequently done by (9) students and always done by only one student. Finally, the results of the fourth action (submit assignments or quizzes) showed that this action always done by (29) participants, and frequently done by (23), however, it rarely done by (6) students and never done by no one. (See Figure 7).

We can conclude from the results that the students are active to the actions that do not involve discussion or interaction while they are passive to the actions that include and require discussions. Such a result confirms the limited participation of the students.

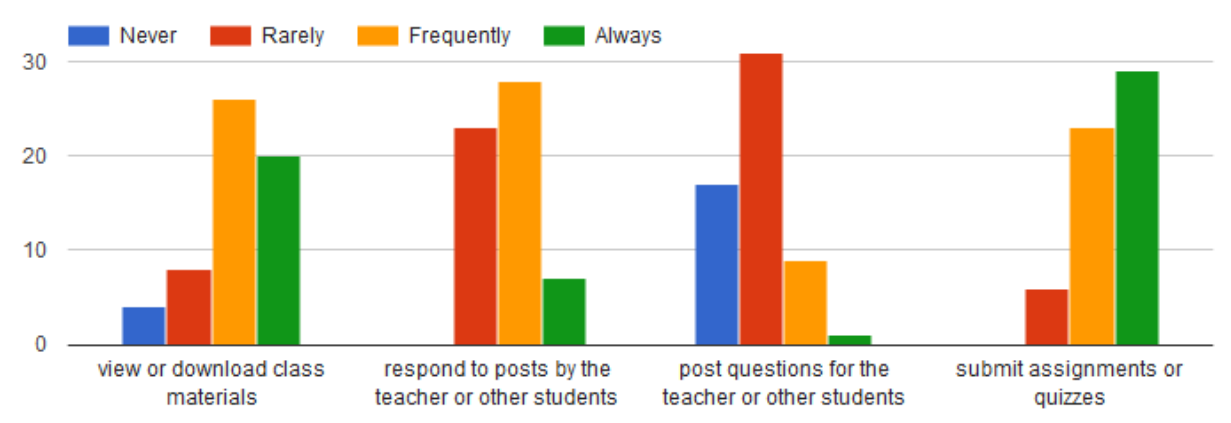

Figure (7) Actions frequently done by students when visiting G-class

To know the students' perceptions about Google Classroom, students were asked about their preference to join, a course where Google Class is used or a course is taught traditionally. Results showed that the majority 
of participants (40) preferred to join the course that uses Google Classroom, while (13) answered either one is fine. However, only (5) students preferred the course that does not use Google Classroom. Figure (8) shows the percentages of choices. This result confirms the students' positive attitude toward Google Classroom.

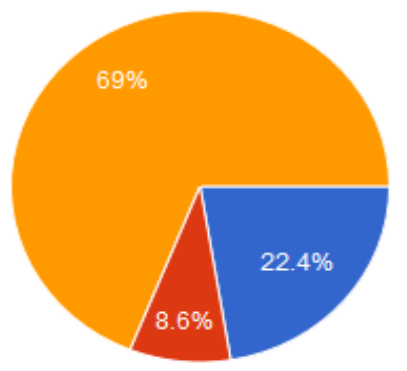

No preference; either one is fine

The one that does not use Google Classroom

The one that uses Google Classroom

Figure (8) students' course preference

The last question of the questionnaire asked the participants how they would rate their Google Classroom experience (Useless $1120 \begin{array}{llll}1 & 2 & 3 & 4\end{array}$ Useful). The results showed that the majority of students $(43.1 \%)$ rated their experience of G-class, was useful. However, only (2) students thought it was useless. Figure (9) shows the percentages. This result also indicates the effectiveness of Google Classroom and confirms students' positive attitude toward G-classroom.

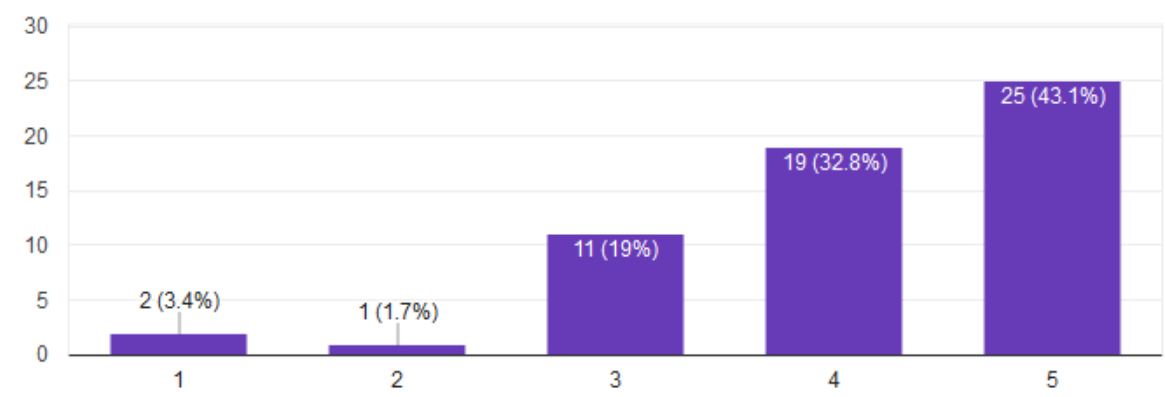

Figure (9) Google Classroom experience 


\section{Summary of the findings and discussion}

This study sought to investigate the causes of passive presence of ELT students' participation on Google Classroom along with exploring the EFL students' attitude toward Google Classroom. The first research question intended to examine passive students' participation in Google Classroom and the hypothesis suggest that this presence of participation may be because of the following themes: technical literacy, Language proficiency and missing tangible outcomes that motivate to participate effectively. Findings refer that participants confirmed technical literacy. Although they have been recruited using an online form, they have reported some technical incompetency. However, the language proficiency is not confirmed to some extent. The majority of the participants are students in the 5th, 6th and 7 th semesters. They have reported little concerns about using English on G-Class. Concerns about the perceived outcomes of G-Class are confirmed. The use of G-Class at the Department of English is still at infancy. Tangible outcomes may be achieved if active participation is rewarded with marks and personalized feedback. (See Figure 10). 


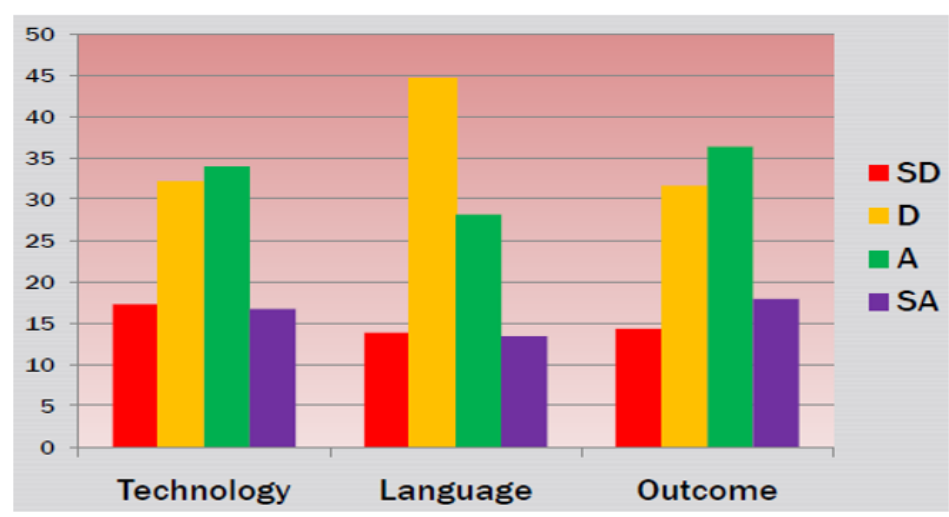

SD = Strongly Disagree $\mathbf{D}=$ Disagree A = Agree $\mathrm{SA}=$ Strongly Agree

Figure (10) Causes of students' passive participation

The second question of the study aimed at identifying EFL students' attitude toward Google Classroom. As is evident in figure (8) that the majority of participants would like to use Google Classroom with other courses in future, and in figure (3) where the students showed high rate of evaluation to the content of Google Classroom, moreover, in figure (2) the majority of participants preferred to join a course that uses Google Classroom, furthermore, in figure (9) the majority of students rated their Google Classroom experience as useful. All the figures mentioned above indicate that most EFL students at English department at Misurata University had positive attitude toward Google Classroom.

\section{Conclusion}

Studies have shown that Cyber Classes offer supplementary instructions that promote self-study and maximize classroom instruction. It provides a lot of exposure, communicative learning environment and enriches knowledge from outside textbooks. The use of multimedia and online technology has positive effects in language teaching and learning. Google 
Classroom, as a platform used in teaching consolidates classroom interactions and provides effort and time for teachers and students. However, EFL students at department of English in Misurata University tend to show limited participation in G-classes. The aim of this study was to explore students' passive participation in Google Classroom, as well as investigating students' attitudes toward it. The results showed that students tend to be passive users of G-classes because of technological concerns, and failure to perceive tangible outcomes. Moreover, it showed that most EFL students have positive attitudes toward Google Classroom.

\section{Recommendations}

Based on the findings and conclusion, the researcher recommends the following ways to reduce the causes of students' limited participation in EFL Google Classrooms:

\section{For teachers}

- Variation of activities on G-Class.

- Provision of individualized feedback.

- Teachers should not be left behind. If teachers themselves are not interested or lack the knowledge of how to effectively utilize technology into teaching, then there will be a kind of communication breakdown between the teachers and their students. Thus, it is the responsibility of the teacher to cope with challenges of the new trend of teaching.

\section{For university}

- Reviewing and modifying regulations so that they fit all matters related to online learning. 
- Enhancing the curricula by including technology courses in order to equip the students with the required knowledge.

- The administration should provide up-to-date facilities and technical resources. For example, an office that provides students and teachers with the help needed in case of any technical issue should exist in each school.

\section{References}

Abukhattala, I. (2016) The Use of Technology in Language Classrooms in Libya. International Journal of Social Science and Humanity, Vol. 6(4), 262-267.

Alfred P. Rovai and Kirk T. Barnum (2003) On-Line Course Effectiveness: An Analysis of Student Interactions and Perceptions of Learning, Journal of Distance Education, Vol. 18 (1), 57-73

Alsowat, A. (2016) An EFL Flipped Classroom Teaching Model: Effects on English Language Higher order Thinking Skills, Student Engagement and Satisfaction. Journal of Education and Practice, Vol. 7 (9), 108-121. www.iiste.org

Arifah. (2014). Study on the use of technology in ELT classroom:

Teachers perspectives. Department of English and Humanities. December 2014. Brac University, Dhaka, Bangladesh. Published Dissertation

Canning-Wilson, (2000) E-Learning, E-Teaching, E-Assessment: Aspects of Course Design for On-Line Web Based Courses Used with EFL/ESL Learners.

DiCicco, Kathleen M. (2016). The Effects of Google Classroom on Teaching Social Studies for Students with Learning Disabilities. Rowan Digital Works. Theses and Dissertations. Paper 1583. 
Flakes, L. (2011) Maximizing Student Learning through a Cyber Classroom. Nagasaki University Comprehensive Environmental Studies, Vol. 14(1), 29-40

Graddol, David. 1997. The Future of English: A Guide to Forecasting the Popularity of the English Language in the 21st Century. London: British Council.

Patel, C. (2013). Use of Multimedia Technology in Teaching and Learning communication skill": An Analysis. International Journal of Advancements in Research \&Technology, Vol 2(7),116-123.

\section{Appendix (A) Online Questionnaire}

\section{Using G- Class in EFL Classroom.}

1- Gender Mark only one oval.

$\longrightarrow$ Male

$\bigcirc$ Female

\section{2- Current level of study}

Mark only one oval.

$\longrightarrow$ 1st or 2nd semester (Freshman)

$\longrightarrow 3$ rd or 4 th semester (Sophomore)

$\square$ 5th or 6th semester (Junior)

$\square 7$ th or 8 th semester (Senior)

3- How often do you have internet access?

Mark only one oval.

$\bigcirc$ Never Rarely Frequently Always

4- Mark only one oval per row.

\begin{tabular}{|l|l|l|l|l|}
\hline & $\begin{array}{l}\text { Strongly } \\
\text { disagree }\end{array}$ & Disagree & Agree & $\begin{array}{l}\text { Strongly } \\
\text { agree }\end{array}$ \\
\hline $\begin{array}{l}\text { I prefer to ask questions for the teacher face-to-face } \\
\text { rather than post them on Google Classroom. }\end{array}$ & & & & \\
\hline $\begin{array}{l}\text { I can understand lessons well even if teachers use } \\
\text { only English to give instructions and explanations. }\end{array}$ & & & & \\
\hline $\begin{array}{l}\text { I learn better, when teachers use Google Classroom } \\
\text { than when they do not. }\end{array}$ & & & & \\
\hline
\end{tabular}


I feel attending some training courses will increase my participation on Google Classroom.

If I have an idea that I can't express in English, I'd rather speak in Arabic than be quiet.

I like the idea of rewarding participation on Google Classroom with marks.

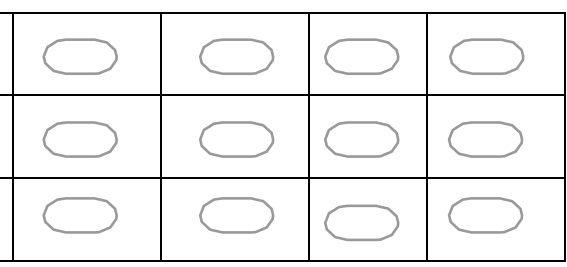

\section{5- Mark only one oval per row.}

\begin{tabular}{|l|l|l|l|l|}
\hline & $\begin{array}{l}\text { Strongly } \\
\text { disagree }\end{array}$ & Disagree & Agree & $\begin{array}{l}\text { Strongly } \\
\text { agree }\end{array}$ \\
\hline $\begin{array}{l}\text { Google Classroom is easy to use (e.g. view class } \\
\text { materials, ask questions, submit assignments). }\end{array}$ & & & & \\
\hline $\begin{array}{l}\text { I prefer if teachers and students could use both } \\
\text { English and Arabic on Google Classroom. }\end{array}$ & & & & \\
\hline $\begin{array}{l}\text { I would like to use Google Classroom with courses } \\
\text { in the future. }\end{array}$ & & & & \\
\hline $\begin{array}{l}\text { Some teachers make Google Classroom less helpful } \\
\text { by insisting on using English. }\end{array}$ & & & & \\
\hline $\begin{array}{l}\text { I will be more active on Google Classroom if my } \\
\text { English gets better. }\end{array}$ & & & & \\
\hline
\end{tabular}

6- On a scale from1to5, how would value the following content of Google Classroom? 1= very low; 5 = very high

Mark only one oval per row

\begin{tabular}{|c|c|c|c|c|c|}
\hline & 1 & 2 & 3 & 4 & 5 \\
\hline Lecture notes/slides & & & & & \\
\hline Group discussion/ interaction & & & & & \\
\hline Assignments/quizzes & & & & & \\
\hline Extra material (explanatory videos, further reading....etc. & & & & & \\
\hline
\end{tabular}

7- How good are you at using the following on line services?

Mark only one oval per row.

\begin{tabular}{|l|l|l|l|l|}
\hline & $\begin{array}{l}\text { None } \\
\text { user }\end{array}$ & $\begin{array}{l}\text { Basic } \\
\text { user }\end{array}$ \\
\hline Social media (facebook, twitter...etc.). & & & & \\
\hline Emailing (Gmail, Yahoo Mail, Hotmail...etc.). & & & & \\
\hline Search engines (Google, Bing, Yahoo...etc.). & & & & \\
\hline Video sharing sites (YouTube, Daily motion...etc.) & & & & \\
\hline $\begin{array}{l}\text { Educational platforms(Google- Classroom, } \\
\text { Edmodo, Moodle ...etc. }\end{array}$ & & & & \\
\hline
\end{tabular}

8- How many courses have you attended in which you have had some online communication with the teacher and/or students?

Mark only one oval. 


\section{None $\longrightarrow 1-3 \bigcirc 4-9 \longrightarrow 10$ or more}

9- How often do you make sure to check Google Classroom for updates?

Mark only one oval.

\begin{tabular}{|l|l|}
\hline & Almost never \\
\hline & Once or multiple times a month \\
\hline & Once or multiple times a week \\
\hline
\end{tabular}

10- When you visit Google Classroom, how often do you find yourself making the following actions?

Mark only one oval per row.

\begin{tabular}{|l|l|l|l|l|}
\hline & Rarely & Frequently & Always \\
\hline view or download class materials. & & & \\
\hline respond to posts by the teacher or other students. & & & & \\
\hline post questions for the teacher or other students. & & & & \\
\hline submit assignments or quizzes. & & & & \\
\hline
\end{tabular}

11- A course taught by the same teacher is offered in two different groups. One group uses Google Classroom while the other does not. Which group would prefer to join?

Mark only one oval

\begin{tabular}{|l|l|}
\hline & No preference; either one is fine \\
\hline & The one that does not use Google Classroom \\
\hline & The one that uses Google Classroom \\
\hline
\end{tabular}

12- Overall, how would rate your Google Classroom experience?

Mark only one oval.

\begin{tabular}{|l|c|c|c|c|c|c|}
\hline & $\mathbf{1}$ & $\mathbf{2}$ & $\mathbf{3}$ & $\mathbf{4}$ & $\mathbf{5}$ & \\
\hline Useless & & & & & & \\
\hline
\end{tabular}

Powered by

:E Google Forms 